\title{
PROFIL PENGGUNAAN OBAT PASIEN PENYAKIT KULIT DI POLIKLINIK KULIT DAN KELAMIN RSU ANUTAPURA PALU
}

\section{DRUG USE PROFILE OF PATIENTS WITH SKIN DISEASE AT DERMATOLOGY AND VENEREOLOGY POLYCLINIC IN ANUTAPURA GENERAL HOSPITAL PALU}

\author{
Fani Oktaviani $^{1 *}$, Alwiyah Mukaddas ${ }^{1}$, Ingrid Faustine ${ }^{1}$ \\ ${ }^{1}$ Jurusan Farmasi, Fakultas MIPA, Universitas Tadulako, Palu, Indonesia
}

Received 20 November 2015, Accepted 25 Januari 2016

\begin{abstract}
ABSTRAK
Penyakit kulit, salah satu penyakit yang masih sangat dominan terjadi dan menjadi masalah kesehatan masyarakat Indonesia, disebabkan oleh infestasi dari bakteri, virus, jamur, parasit atau reaksi alergi. Penyakit kulit dapat diobati dengan bermacam-macam cara, antara lain rute topikal, sistemik, dan atau intralesi. Penelitian ini bertujuan untuk mengetahui profil penggunaan obat pasien penyakit kulit di Poliklinik Kulit dan Kelamin RSU Anutapura Palu dengan menggunakan metode prospektif dan penyajian data secara deskriptif. Hasil penelitian ini menunjukkan bahwa dari 98 pasien, sebagian besar berjenis kelamin laki-laki 53,06\%, berumur 41-65 tahun 55,10\%, 27,55\% berpekerjaan sebagai IRT (Ibu Rumah Tangga), dan ditemukan 100\% pasien bermanifestasi klinik berupa ruam dengan diagnosa terbanyak adalah psoriasis vulgaris sebanyak $13,26 \%$. Jumlah pasien yang mendapatkan variasi jumlah 4-6 obat adalah sebesar $68,37 \%$ dimana berdasarkan total frekuensi jenis obat yang digunakan (381), kelas terapi obat yang terbanyak adalah antiinflamasi topikal golongan kortikosteroid $(23,10 \%)$, seperti desoksimetason $(18,11 \%)$; sedangkan berdasarkan frekuensi bentuk sediaan obat (213), tablet adalah yang paling dominan digunakan (43,19\%). Hasil yang diperoleh telah sesuai dengan Standar Pelayanan Medis (SPM) RSU Anutapura Palu.
\end{abstract}

Kata Kunci: Profil penggunaan obat, Penyakit Kulit, Antiinflamasi, Kortikosteroid.

\begin{abstract}
Skin diseases, one type of diseases that is still very dominant occuring and becoming one public health problem in Indonesia, are caused by bacteria, viruses, fungi, parasite infestations or allergic reactions. They can be treated with various ways including topical, systemic and or intralesional routes. This study aimed to determine the drug use profile of patients with skin disease at Dermatology and Venereology Polyclinic in Anutapura General Hospital Palu using prospective method and data were descriptively presented. The results showed that from 98 patients, there was $53.06 \%$ male; $55.10 \%$ aged $41-65$ years; and $27.55 \%$ housewifes and it was found that $100 \%$ of them had clinical manifestation of rash in which the most diagnosis of skin disease was Psoriasis vulgaris as much as $13.26 \%$. Patients receiving 4-6 amount of drug variation were $68.37 \%$ that based on total frequency of the type of drugs used (381), the most class of therapy was topical corticosteroid antiinflammatory drugs $(23.10 \%)$, such as desoximetasone $(18.11 \%)$; while based on frequency of the drug dosage forms (213), tablet was the most dominant one (43.19\%). This results were in accordance with the Standards of Medical Care of Anutapura General Hospital Palu.
\end{abstract}

Keywords: Drug Use Profile, Skin Diseases, Anti-Inflammatory, Corticosteroids.

*Coresponding Author : Fani oktaviani, fani.oktaviani_53@yahoo.co.id 


\section{PENDAHULUAN}

Penyakit kulit merupakan salah satu penyakit yang masih sangat dominan terjadi dan menjadi masalah kesehatan masyarakat Indonesia. Data Profil Kesehatan Indonesia 2008 menunjukkan bahwa distribusi pasien rawat jalan menurut International Classification of Diseases10 (ICD-10) di rumah sakit di Indonesia tahun 2008 dengan golongan sebab sakit "Penyakit Kulit dan Jaringan Subkutan" terdapat sebanyak 64.557 pasien baru (Depkes, 2009). Hal ini juga dibuktikan dari data Profil Kesehatan Indonesia 2010 yang menunjukkan bahwa penyakit kulit dan jaringan subkutan menjadi peringkat ketiga dari 10 penyakit terbanyak pada pasien rawat jalan di rumah sakit se-Indonesia berdasarkan jumlah kunjungan yaitu sebanyak 192.414 kunjungan dan 122.076 kunjungan diantaranya merupakan kasus baru (Kemenkes, 2011).

Berdasarkan penelitian studi epidemiologi penyakit kulit dan pengobatan di India, menyatakan bahwa penyakit kulit menyumbang 10-20\% dari semua konsultasi dalam praktek umum. (Patel, 2010). Data yang didapatkan dari beberapa studi dengan tema prevalensi penyakit kulit berbasis komunitas di negara berkembang mengindikasikan bahwa penyakit kulit di negara berkembang sering ditemukan, yaitu sekitar 2080\% (Al-Hoqail, 2013).

Berdasarkan data unit rekam medis 10 penyakit terbesar di Poliklinik Rumah Sakit Umum Anutapura Palu pada tahun 2012 hingga 2014 terjadi peningkatan jumlah kasus penyakit kulit setiap tahun yaitu 669 kasus, 700 kasus, hingga 738 kasus dan menempati urutan ke empat di tahun 2014. Melihat semakin bertambahnya angka kejadian penyakit kulit, menuntut adanya berbagai upaya untuk meningkatkan mutu layanan kesehatan. Profil penggunaan obat pasien penyakit kulit akan membantu tenaga kesehatan dalam meningkatkan terapi yang optimal pada pasien. Hal ini yang mendasari peneliti untuk melakukan penelitian terkait profil penggunaan obat pasien penyakit kulit di Poliklinik Kulit dan Kelamin RSU Anutapura Palu periode Maret sampai Juni 2015.

\section{METODE PENELITIAN Jenis Penelitian}

Jenis penelitian ini adalah penelitian deskriptif yang dikerjakan secara prospektif dan hasil penelitian disajikan secara narasi atau gambaran.

\section{Waktu dan Tempat Penelitian}

Waktu penelitian berlangsung pada periode Maret sampai dengan Juni 2015. Penelitian ini dilakukan di Rumah Sakit Umum Anutapura Palu Provinsi Sulawesi Tengah.

\section{Sampel}

Sampel pada penelitian ini adalah pasien penyakit kulit yang berkunjung ke Poliklinik Kulit dan Kelamin RSU Anutapura Palu periode Maret - Juni 2015 yang memenuhi kriteria inklusi dan eksklusi. Pengumpulan data yaitu pengumpulan data sekunder, dilakukan dengan cara mencatat isi rekam medik.

\section{Analisis Data}

Teknik analisis data yang digunakan dalam penelitian ini adalah analisa univariat. Pada umumnya dalam analisis ini hanya menghasilkan distribusi frekuensi dan persentase dari tiap variable.

\section{HASIL DAN PEMBAHASAN}

\section{Hasil}

Tabel 1. Karakteristik Demografis pasien penyakit kulit di Poliklinik Kulit dan Kelamin RSU Anutapura Palu pada bulan Maret sampai Juni 2015.

\begin{tabular}{lcc}
\hline \multicolumn{1}{c}{ Karakteristik Demografi } & Jumlah Pasien & Persentase (\%) \\
\hline Jenis Kelamin & & \\
Laki-laki & 52 & 53,06 \\
Perempuan & 46 & 46,94 \\
Umur & & \\
0 bln -2 thn & 2 & \\
$3-5$ thn & 1 & 2,04 \\
$6-12$ thn & 3 & 1,02 \\
$13-18$ thn & 10 & 3,06 \\
$19-40$ thn & 18 & 10,20 \\
$41-65$ thn & 54 & 18,37 \\
$>65$ thn & 10 & 55,10 \\
& & 10,20 \\
Pekerjaan & & \\
IRT & 27 & \\
PNS & 19 & 27,55 \\
Pelajar & 16 & 19,39 \\
Wiraswasta & 15 & 16,33 \\
Petani & 4 & 15,31 \\
Pegawai Swasta & 2 & 4,08 \\
Tidak bekerja & 15 & 2,04 \\
& 98 & 15,31 \\
& & 100 \\
\hline
\end{tabular}


Tabel 2. Distribusi Karakteristik Klinik pasien penyakit kulit di Poliklinik Kulit dan Kelamin RSU Anutapura Palu pada bulan Maret sampai Juni 2015.

\begin{tabular}{ccc}
\hline Manifestasi Klinik & Jumlah Pasien & $(\boldsymbol{\%})$ \\
\hline Ruam & 98 & 100 \\
Gatal & 90 & 91,83 \\
Nyeri & 6 & 6,12
\end{tabular}

\begin{tabular}{|c|c|c|}
\hline Diagnosa & Jumlah Pasien & $(\%)$ \\
\hline Psoriasis Vulgaris & 13 & 13,26 \\
\hline Dermatitis Seboroik & 10 & 10,20 \\
\hline Dermatitis Non Spesifik & 8 & 8,16 \\
\hline Skabies & 7 & 7,14 \\
\hline Neurodermatitis & 7 & 7,14 \\
\hline HerpesZoster & 4 & 4,08 \\
\hline Dermatitis Numularis & 3 & 3,06 \\
\hline Dermatitis Atopi & 2 & 2,04 \\
\hline Dermatitis Impetigenisata & 2 & 2,04 \\
\hline Eritema Nodosum Leprosum & 2 & 2,04 \\
\hline Kandidiasis Intertiginosa & 2 & 2,04 \\
\hline Prurigo Nodularis & 2 & 2,04 \\
\hline Skabies + DS & 2 & 2,04 \\
\hline Tinea Korporis & 2 & 2,04 \\
\hline Tinea Kruris & 2 & 2,04 \\
\hline Tinea Korporis + Tinea Kruris & 2 & 2,04 \\
\hline Urtikaria Kronik & 2 & 2,04 \\
\hline Alopesia Areata + Furunkel & 1 & 1,02 \\
\hline Dermatitis Alinmentary & 1 & 1,02 \\
\hline DKA + DNS & 1 & 1,02 \\
\hline DNS + Infeksi Sekunder & 1 & 1,02 \\
\hline DS + Kandidiasis Intertiginosa & 1 & 1,02 \\
\hline DS + Pruritus Sinilis & 1 & 1,02 \\
\hline DS + Tinea Kruris & 1 & 1,02 \\
\hline DS + Tinea Unguinum & 1 & 1,02 \\
\hline Diagnosa & Jumlah Pasien & $(\%)$ \\
\hline Hiperplasia Sebasea & 1 & 1,02 \\
\hline Hiperpigmentasi Post Inflamasi & 1 & 1,02 \\
\hline HPI + Pioderma & 1 & 1,02 \\
\hline HPI + Pitiriasis Versikolor & 1 & 1,02 \\
\hline Insect Bite & 1 & 1,02 \\
\hline Kandidiasis Intertiginosa + DKA & 1 & 1,02 \\
\hline Karbunkel & 1 & 1,02 \\
\hline Miliaria & 1 & 1,02 \\
\hline Prurigo Nodularis + HPI & 1 & 1,02 \\
\hline Pruritus Sinilis & 1 & 1,02 \\
\hline Psoriasis Gutatea + HPI & 1 & 1,02 \\
\hline Psoriasis Folikolitis & 1 & 1,02 \\
\hline Selulitis + Pruritus Sinilis & 1 & 1,02 \\
\hline Tinea Fasialis & 1 & 1,02 \\
\hline Tinea Korporis + Pitiriasis Versikolor & 1 & 1,02 \\
\hline Tinea Pedis & 1 & 1,02 \\
\hline Virtiligo & 1 & 1,02 \\
\hline Xerosis Cutis & 1 & 1,02 \\
\hline Jumlah & 98 & 100 \\
\hline
\end{tabular}

DS: Dematitis Seboroik; DKA: Dermatitis Kontak Alergi; DNS: Dematitis Non Spesifik; ENL: Eritema Nodosum Leprosum; HPI: Hiperpigmentasi Post Inflamasi
Tabel 3. Profil penggunaan obat pasien penyakit kulit di Poliklinik Kulit dan Kelamin RSU Anutapura Palu pada bulan Maret sampai Juni 2015

\begin{tabular}{|c|c|c|c|c|c|}
\hline $\begin{array}{c}\text { Rute } \\
\text { Pemberian }\end{array}$ & Kelas Terapi & Golongan & Jenis Obat & Frek & $(\%)$ \\
\hline \multirow{20}{*}{ Oral } & \multirow{4}{*}{ Antihistamin } & \multirow{4}{*}{$\begin{array}{l}\text { Antagonis } \\
\text { Reseptor H1 }\end{array}$} & $\begin{array}{c}\text { Setirizin } \\
\text { Dihidroklorida }\end{array}$ & 59 & 15,49 \\
\hline & & & $\begin{array}{l}\text { Klorfeniramin } \\
\text { Maleat }\end{array}$ & 1 & 0,26 \\
\hline & & & $\begin{array}{l}\text { Mebhidrolin } \\
\text { Napadisilat }\end{array}$ & 4 & 1,05 \\
\hline & & & Loratadin & 18 & 4,72 \\
\hline & Antijamur & Azol & Ketokonazol & 4 & 1,05 \\
\hline & Antiakne & Retinoid & Isotretinoin & 1 & 0,26 \\
\hline & \multirow{4}{*}{ Antiinflamasi } & \multirow{3}{*}{ Kortikosteroid } & Metilprednisolon & 10 & 2,62 \\
\hline & & & & & \\
\hline & & & Prednis on & 2 & 0,52 \\
\hline & & NSAID & $\begin{array}{c}\text { Natrium } \\
\text { Diklofenak }\end{array}$ & 5 & 1,31 \\
\hline & \multirow{5}{*}{ Antibiotik } & Sefalosporin & & & \\
\hline & & (Gen. 1) & Sefadroksil & 4 & 1,05 \\
\hline & & & & & \\
\hline & & Tetrasiklin & Doks is iklin & 1 & 0,26 \\
\hline & & Makrolida & Eritromisin & 1 & 0,26 \\
\hline & Antiviral & Guanosin Asiklik & Asiklovir & 2 & 0,52 \\
\hline & $\begin{array}{l}\text { Analgesik, } \\
\text { antipiretik }\end{array}$ & $\begin{array}{l}\text { Para Amino } \\
\text { Fenol }\end{array}$ & Parasetamol & 2 & 0,52 \\
\hline & Antinyeri & & & & \\
\hline & (off-label use) & Trisiklik (TCA) & Amitriptilin & 2 & 0,52 \\
\hline & Vitamin & Multivitamin & Vit. B Kompleks & 6 & 1,57 \\
\hline \multirow{14}{*}{ Topikal } & \multirow{4}{*}{ Antiinflamasi } & \multirow{4}{*}{ Kortikosteroid } & Betametas on & 3 & 0,79 \\
\hline & & & Desoksimetason & 69 & 18,11 \\
\hline & & & $\begin{array}{l}\text { Mometason } \\
\text { Furoat }\end{array}$ & 7 & 1,84 \\
\hline & & & Hidrokortis on & 9 & 2,36 \\
\hline & \multirow{5}{*}{ Antiparasit } & \multirow{5}{*}{ Ektoparasitisida } & Mikonazol & 37 & 9,71 \\
\hline & & & Ketokonazol & 15 & 3,94 \\
\hline & & & Permetrin & 9 & 2,36 \\
\hline & & & Sulfur & 7 & 184 \\
\hline & & & Sипит & 1 & 1,04 \\
\hline & \multirow{3}{*}{ Antibiotik } & Steroidal & Asam fusidat & 52 & 13,65 \\
\hline & & & & & \\
\hline & & Antimikroba lain & Mupirosin & 1 & 0,26 \\
\hline & \multirow[t]{2}{*}{ Keratolitik } & \multirow[t]{2}{*}{ Salisilat } & Asam Salisilat & 50 & 13,12 \\
\hline & & & & \multicolumn{2}{|l|}{381} \\
\hline \multicolumn{3}{|c|}{ Variasi Jumlah Obat } & ah Pasien & \multicolumn{2}{|l|}{$(\%)$} \\
\hline \multicolumn{3}{|c|}{$1-3$} & 31 & 31,63 & \\
\hline \multirow{2}{*}{\multicolumn{3}{|c|}{$4-6$}} & 67 & 68,37 & \\
\hline & & & 98 & 100 & \\
\hline \multicolumn{3}{|c|}{ Bentuk Sediaan } & Frek & $(\%)$ & \\
\hline \multicolumn{3}{|c|}{ Tablet } & 92 & 43,19 & \\
\hline \multicolumn{3}{|c|}{ Salep } & 70 & 32,86 & \\
\hline & Krim & & 42 & 19,72 & \\
\hline & Pulvis & & 2 & 0,94 & \\
\hline & Shampo & & 7 & 3,29 & \\
\hline & & & 213 & 100 & \\
\hline
\end{tabular}




\section{Pembahasan}

Pada Tabel 1 tentang karakteristik demografis pasien penyakit kulit untuk jenis kelamin, pasien berjenis kelamin laki-laki berjumlah 52 pasien $(53,06 \%)$, sedangkan pasien perempuan berjumlah 46 pasien $(46,94 \%)$. Hal ini menunjukkan bahwa lakilaki lebih dominan terkena penyakit kulit. Hasil penelitian lain yang sejalan dilakukan oleh Gunawan pada tahun 2012 diperoleh hasil yang telah sesuai. Sebanyak 41 pasien penyakit kulit dalam hal ini skabies, jumlah pasien laki-laki lebih banyak $(63,41 \%)$ dari pada jumlah pasien perempuan (36,59\%). Dari segi usia, usia yang terbanyak 41-65 tahun $(55,10 \%)$. Penelitian lain menunjukkan bahwa kelompok umur terbanyak yang menderita penyakit kulit dalam hal ini dermatitis kontak adalah kelompok umur 45 - 64 tahun (Yurike, 2012). Pekerjaan pasien penyakit kulit terbanyak yaitu $27,55 \%$ (27 pasien) berstatus sebagai Ibu Rumah Tangga (IRT); 19,39\% (19 pasien) bekerja sebagai PNS; 16,33\% (16 pasien) berstatus sebagai pelajar; $15,31 \%$ (15 pasien) bekerja sebagai wiraswasta; 4,08\% (4 pasien) bekerja sebagai petani; 2,04\% (2 pasien) bekerja sebagai pegawai swasta dan 15,31\% (15 pasien) tidak bekerja.

Pada tabel 2 tentang karakteristik klinis pasien penyakit kulit dari 98 pasien penyakit kulit sebanyak 100\% (98 pasien) mengalami ruam atau kelainan pada kulit; 91,83\% (90 pasien) mengalami gatal-gatal dan sedikitnya $6,12 \%$ (6 pasien) merasakan nyeri yaitu dominan pada pasien herpes zoster. Ruam yang sering ditemui pada penderita penyakit kulit yaitu eritema yang terjadi pada hampir semua penyakit kulit, vesikel pada skabies dan herpes zoster, makula dan skuama pada pitiriasis versikolor. Diagnosa terbanyak yaitu 13,26\% (13 pasien) menderita psoriasis $\mathrm{v}$ ulgaris; $10,20 \%$ (10 pasien) menderita dermatitis seboroik; $8,16 \%$ (8 pasien) menderita dermatitis non spesifik dan 7,14\% (7 pasien) menderita skabies dan neurodermatitis. Psoriasis vulgaris adalah penyakit autoimun bersifat kronik residif yang termasuk dalam kelompok dermatosis eritroskuamosa, dengan lesi berupa makula eritem berbatas tegas, ditutupi oleh skuama kasar berlapis. Psoriasis vulgaris ini merupakan jenis psoriasis yang sangat umum dan sering terjadi pada masyarakat dengan jumlah penderitanya yang lebih banyak dibandingkan penderita psoriasis lainnya. Penyakit ini dapat mengenai semua kelompok umur, walaupun pada bayi dan anak-anak jarang, dan tidak ada perbedaan antara lakilaki dan wanita.

Pada tabel 3 tentang karakteristik profil penggunaan obat pasien penyakit kulit, untuk variasi jumlah obat yang diberikan kepada pasien, dari 98 pasien sebesar 68,37\% (67 pasien) diberikan $4-6$ obat dan 31,63\% (31 pasien) diberikan $1-3$ obat. Jumlah pemberian obat yang diberikan bervariasi karena dari 98 pasien terdapat berbagai macam diagnosa penyakit kulit dengan manifestasi klinis yang berbeda sehingga jumlah obat yang diberikan juga lebih variatif. Untuk kelas terapi obat pasien penyakit kulit, dari 98 pasien penyakit kulit dapat diketahui menggunakan dua rute pemberian yaitu topikal dan oral. Pemberian secara topikal yang paling dominan yaitu kelas terapi antiinflamasi sebesar $23,10 \%$ dan antibiotik sebesar 13, 91\%. Sedangkan pemberian secara oral yang paling dominan yaitu kelas terapi antihistamin sebesar $21,52 \%$. Hasil penelitian menunjukkan antiinflamasi topikal dan antihistamin oral paling banyak digunakan. Antiinflamasi golongan kortikosteroid topikal merupakan terapi utama pada sebagian besar dermatosis peradangan. Kortikosteroid juga mempunyai indikasi penggunaan yang sangat luas, yaitu anti inflamasi, anti alergi, antipruritus, anti mitotik dan vasokontriksi. Sedangkan antihistamin bertujuan untuk mengurangi rasa gatal yang timbul akibat proses alergi. Antihistamin dapat mencegah urtikaria dan digunakan untuk mengatasi ruam kulit pada urtikaria, gatal, gigitan dan sengatan serangga, serta alergi obat. Hasil yang didapatkan juga telah sesuai dengan penelitian Yurike (2012) yang menyatakan pemberian terapi tersering dalam hal ini dermatitis kontak yaitu kortikosteroid dan antihistamin.

Sebanyak 98 pasien penyakit kulit, yang menggunakan jenis obat kelas terapi antiinflamasi adalah desoksimetason sebesar $18,11 \%$ (69 pasien) dan yang menggunakan jenis obat kelas terapi antihistamin adalah setirizin dihidroklorida sebesar $15,49 \%$ (59 pasien).

Desoksimetason adalah golongan obat kortikosteroid yang diketahui memiliki efek yang berhubungan dengan kemampuannya 
untuk merangsang biosintesis protein lipomodulin, yang dapat menghambat kerja enzimatik fosfolipase $A_{2}$ sehingga mencegah pelepasan mediator proses peradangan, yaitu asam arakidonat dan metabolitnya, seperti prostaglandin (PG), leukotrien (LT), tromboksan dan prostasiklin yang dapat menyebabkan nyeri, efek vasodilatasi, penimbunan leukosit dan efek fagositosis yang menyebabkan kerusakan jaringan (Siswandono \& Soekardjo, 2008).

Setirizin dihidroklorida adalah golongan antihistamin yang merupakan antihistamin generasi kedua (antihistamin selektif), antagonis reseptor $\mathrm{H} 1$ periferal dengan efek sedatif (kantuk) yang rendah pada dosis aktif farmakologi atau dosis yang dianjurkan. Mekanisme kerja antihistamin ini yaitu antagonis reseptor histamin $\mathrm{H} 1$ berikatan dengan reseptor $\mathrm{H} 1$ tanpa mengaktivasi reseptor, yang mencegah ikatan dan kerja histamin (Siswandono \& Soekardjo, 2008).

Bentuk sediaan obat pasien penyakit kulit, ada 5 yang diberikan kepada pasien sesuai kebutuhan. Bentuk sediaan yang digunakan yaitu tablet sebanyak 43,19\%, salep $32,86 \%$, krim sebanyak $19,72 \%$, pulvis $0,94 \%$, dan shampo sebanyak $3,29 \%$. Hal ini menunjukkan bahwa bentuk sediaan yang paling banyak diberikan adalah tablet, namun jika dijumlahkan bentuk sediaan salep, krim, pulvis dan shampoo maka hasil diperoleh telah sesuai bahwa rute pemberian terbanyak dalam pengobatan penyakit kulit di Poliklinik Kulit dan Kelamin RSU Anutapura Palu yaitu secara topikal. Standar Pelayanan Medis (SPM) penyakit kulit dan kelamin RSU Anutapura Palu tahun 2009, juga menyatakan bahwa bentuk-bentuk sediaan tersebut digunakan dalam terapi penyakit kulit di RSU Anutapura Palu.

\section{DAFTAR PUSTAKA}

Al-Hoqail, I.A. (2013). Epidemiological spectrum of common dermatological conditions of patients attending dermatological consultations in AlMajmaah Region (Kingdom of Saudi Arabia), J Taibah Univ Med Sci.

Departemen Kesehatan Republik Indonesia. (2009). Profil Kesehatan Indonesia 2008. Departemen Kesehatan Republik Indonesia. Jakarta.

Gunawan, Made Erik Sastra. (2012). Profil Skabies di Poliklinik Kulit dan Kelamin BLU RSUP Prof. Dr. R. D. Kandou Manado Periode Januari - Desember 2012. Jurnal. Universitas Sam Ratulangi. Manado.

Kementrian Kesehatan Republik Indonesia. (2011). Profil Kesehatan Indonesia 2010. Kementrian Kesehatan Republik Indonesia. Jakarta.

Patel, Nailesh G. (2010). Asian Journal of Pharmaceutical and Clinical Research. Department of Pharmacology. Gujarat, India.

Siswandono, \& Soekardjo, B. (2008). Kimia Medisinal, Edisi 2. Airlangga University Press. Surabaya.

Yurike, Sunaryo. (2012). Profil Dermatitis Kontak di Poliklinik Kulit dan Kelamin BLU RSUP Prof. Dr. R. D. Kandou Manado Periode Januari - Desember 2012. Jurnal. Universitas Sam Ratulangi. Manado. 
